\title{
Republic of Korea's Energy Security Conundrum: The Problems of Energy Mix and Energy Diplomacy Deadlock*
}

\begin{abstract}
Se Hyun Ahn
This paper explores Republic of Korea (ROK)'s energy security priorities and problems. During the President Park's administration, ROK has faced wide range of energy security problems. Almost nation's energy diplomacy has virtually stopped to function for mostly domestic political reasons. Furthermore, nation's energy security has been endangered because ROK's energy security policy has poorly implemented with no concrete goals and no rational choice of energy mix plan. This study seeks to examine ROK's most urgent energy security agenda at the moment and how the country should response to these specific issues. Moreover, this study will investigate ROK's energy mix policy in detail according to various energy resources. This paper contends that the current problems of ROK's energy security and the deadlock of ROK's energy diplomacy stemmed from the ignorance of the exact definition of energy security at the national level among policy makers, academia, various political groups including top leadership. ROK's energy security is highly likely to experience significant disarray in the upcoming decades since nation's energy security clock has been reset back to 5 years before now during the Park's administration.
\end{abstract}

Keywords: Energy Security, Republic of Korea, Energy Mix, the U.S., Russia, Energy Diplomacy

\section{INTRODUCTION}

This paper explores Republic of Korea (ROK)'s energy security priorities and problems. During the President Park's administration, ROK has faced wide range of energy security problems. Almost all of the nation's energy diplomatic efforts has virtually stopped to function for mostly domestic political reasons and energy security has been endangered because ROK's energy security policy has been poorly implemented with no concrete goals and no rational choice of energy mix plan. Regardless of ROK's current energy security policy problems, this study intends to examine ROK's most urgent energy security agenda at the moment and how the country should response to these specific issues.

Before examining the individual energy security issues, this article also outlines the exact definition of energy security and how this concept has evolved in the past century. Moreover, this study seeks to highlight ROK's energy mix policy in detail according to various energy resources. This study contends that the current problems of ROK's energy security and the deadlock of ROK's energy diplomacy stemmed from the ignorance of the exact definition of energy security at the national level among policy makers, academia, various political groups including top leadership. In the upcoming decades, ROK's energy security is likely to experience significant disarray since nation's energy security clock has been reset back to 5 years before during the Park's administration. There is a grave concern that ROK's energy diplomacy has lost 5 years and will face a great deal of setback in the future.

\footnotetext{
* This work was supported by the 2014 Sabbatical Research Grant of the University of Seoul.
} 


\section{ROK ENERGY CONSUMPTION AND DEMAND TREND}

South Korea is desperately in need of vast amounts of natural resources to keep up with its fast economic growth. Nonetheless, South Korea has very limited domestic sources of energy, and relies almost completely on imports. As an energy-poor country with insufficient natural resources, as table 1 indicates, ROK has an energy import dependency ratio of $96 \%$ while ranking $10^{\text {th }}$ in the world in energy consumption. Consumption of oil, gas, and coal ranks $9^{\text {th }}, 16^{\text {th }}$ and $13^{\text {th }}$ in the world respectively, and imports of oil, gas, and coal rank $5^{\text {th }}, 6^{\text {th }}$ and $3^{\text {rd }}$ in the world. For instance, energy imports as a percentage of total demand rose from $73.5 \%$ in 1980 to $96.8 \%$ in 2005. And South Korea imports all of its oil needs. While South Korea remains the world's fourth largest oil consumer, and at present is the main fuel used in Korea, demand for oil as a percentage of total energy demand is projected to fall from 53\% in 2003 to $39 \%$ by 2030 (Ministry of Trade, Industry \& Energy, 2014).

\subsection{Global Supply and Demand Conditions}

Table 1. Fossil Fuel Self-sufficiency Rates of the World's Ten Largest Energy Consumers (2011)

\begin{tabular}{ccccc}
\hline Ranking & Country & Oil & Gas & Coal \\
\hline 1 & China & 0.46 & 0.78 & 0.98 \\
2 & U.S. & 0.46 & 0.93 & 1.12 \\
3 & India & 0.26 & 0.76 & 0.77 \\
4 & Russia & 3.25 & 1.41 & 1.55 \\
5 & Japan & 0.00 & 0.03 & 0.00 \\
6 & Germany & 0.03 & 0.16 & 0.60 \\
7 & France & 0.01 & 0.01 & 0.01 \\
8 & Canada & 2.12 & 1.58 & 1.72 \\
9 & Brazil & 1.03 & 0.62 & 0.14 \\
10 & Korea & 0.01 & 0.01 & 0.01 \\
\hline
\end{tabular}

Source: Ministry of Trade, Industry \& Energy. 2014. "Korea Energy Master Plan: outlook \& policies to 2030” Ministry of Trade, Industry \& Energy. p.52.

\subsection{Current Energy Consumption}

The ROK's average annual growth rate (AAGR) of final energy consumption from 2000 to 2012 was $2.8 \%$, as figure 1 suggests. In fact, the AAGR which was $7.2 \%$ during the $1990 \mathrm{~s}$, decreased significantly following the financial crisis in 1998. It is also important to note that the share of energy consumed in the industrial sector has been increasing and currently constitutes more than $60 \%$ of final energy consumption, whereas the portion of the household, commercial, public and transportation sectors decreased steadily (Ministry of Trade, Industry \& Energy, 2014).

As for oil, the total share of oil in ROK's final energy consumption reached a record high of $68.2 \%$ in 1994 but since then began to decrease to $48.4 \%$ in 2013. Also, ROK's oil AAGR reached $8.0 \%$ in the $1990 \mathrm{~s}$ but also decreased to $1.0 \%$ in the $2000 \mathrm{~s}$. ROK's oil AAGR by product is as follows: gasoline $1.2 \%$, diesel for transportation $1.4 \%$, kerosene/light oil $-2.9 \%$, 
Figure 1. Final Energy Consumption Trend By Source (Unit:\%)

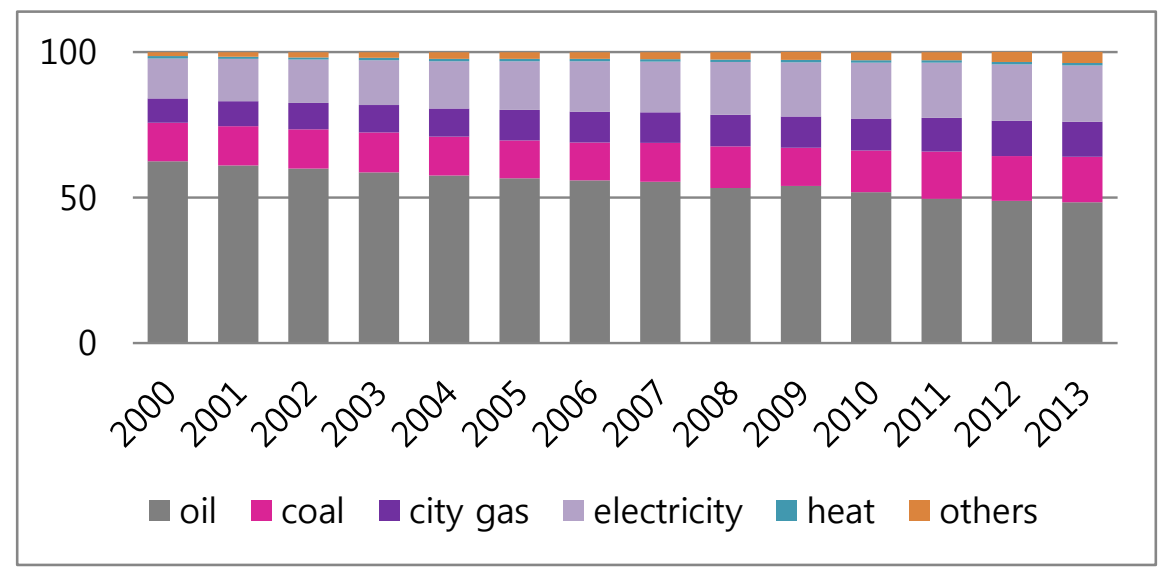

Source: Korea Energy Economics Institute. 2014. "Yearbook of Energy Statistics." Korea Energy Economics Institute.

heavy oil $-8.2 \%$, naphtha $4.4 \%$. Also, oil share by sector is as follows: Industry $55.6 \%$, transportation $36.3 \%$, household/commerce $6.9 \%$. Furthermore, excluding feedstock is as follows: Industry $14.5 \%$, transportation $70.2 \%$, household/commerce $13.1 \%$ (Ministry of Trade, Industry \& Energy, 2014).

As far as the electricity consumption is concerned, it increased from $10.8 \%$ in 1990 to $19.3 \%$ in 2012, primarily because the electricity price in ROK is exceptionally low, compared to other energy resources, and the use of electricity was quite convenience in ROK.

As for City Gas: Consumption of city gas in the ROK increased quite dramatically at an AAGR of $30.5 \%$ in the 1990 s, as figure 2 indicates, but this increase also declined somehow to an AAGR of $5.9 \%$ after 2000 due to saturation of infrastructure. AAGR by sector from 2000 is as follows: industry $9.3 \%$, household/commerce $3.6 \%$ (Ministry of Trade, Industry \& Energy, 2014).

Coal consumption also gradually began to increase. The share of coal use remained in the $13 \%$ range in the 2000 s, but since then rose up to $15.4 \%$ in 2012 because industrial coal consumption increased. Moreover, the share of bituminous coal in total coal consumption, which was $50.4 \%$ in 1990 , increased sharply to $91.8 \%$ in 2012 due to a decrease in anthracite coal consumption and an increase in the use of bituminous coal for power generation (Ministry of Trade, Industry \& Energy, 2014).

\subsection{Problems of the Current Energy Policy}

A general trend of low-price policy motivated by social and economic domestic pressures at the national level has facilitated energy overconsumption patterns and accelerated the social trend toward disproportionate use of certain types of energy, mostly electricity. In particular, exceptionally low electricity price in ROK turn out also a significant obstacle to the creation of new markets in less economical arena, such as renewable energy and smart grid sector. 
Figure 2. Change in Energy Mix (2001 $\rightarrow 2012)$
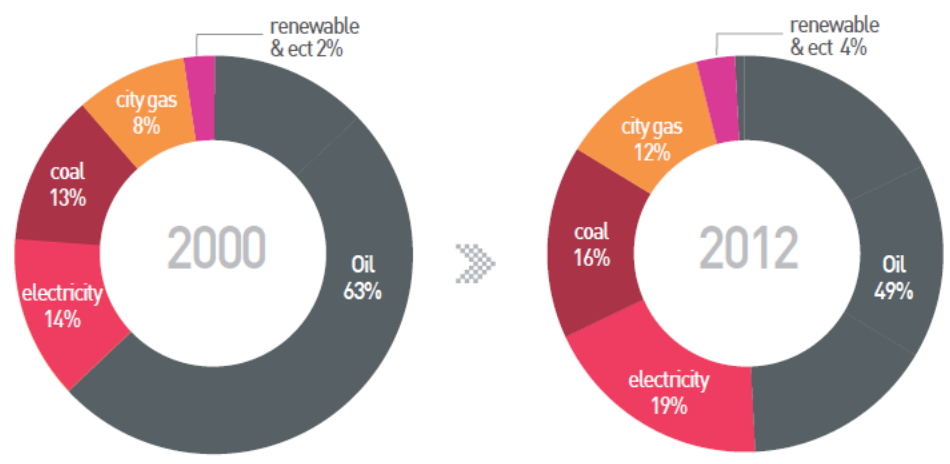

- In particular, the electrification of enerqy consumption is causing serious problems.

Source: Ministry of Trade, Industry \& Energy. 2014. "Korea Energy Master Plan: outlook \& policies to 2030." Ministry of Trade, Industry \& Energy. p.28.

The current energy mix is also problematic because it did not fully take external environment into account. In this regard, there should be many considerations of external factors including environmental pollution caused by nuclear and coal-fired plants, public safety concerns, opposition from local residents, security costs and etc (Ministry of Trade, Industry \& Energy, 2014).

\subsection{Basic Direction of the Second Energy Master Plan}

Transition to demand management policy

The ROK's second energy master plan aimed at demand management policy, more specifically, adjustment of domestic energy prices. Due to the ROK government's price

Figure 3. International Prices for Heavy Oil, LNG, and Electricity

(USD/TOE)

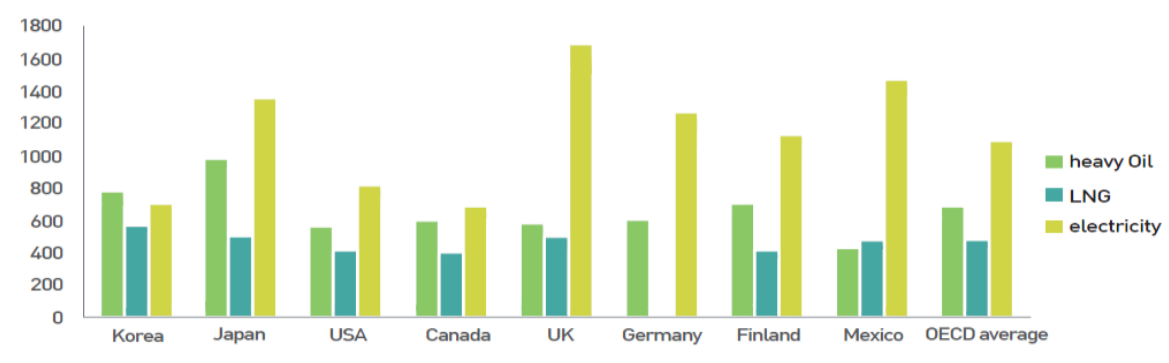

- Korea is the only country where heavy oil (blue) is more expensive than electricity (green).

Source: Ministry of Trade, Industry \& Energy. 2014. "Korea Energy Master Plan: outlook \& policies to 2030." Ministry of Trade, Industry \& Energy. p.56. 
liberalization policy, as figure 3 indicates, the price of electricity has consistently been lower than the price of oil, which was taxed at a rate of up to 50\%, worsening distortions in energy consumption.

Another explanation of energy price distortion in energy consumption is that electricity rates do not sufficiently reflect the environmental and social costs of power generation in Korea. For example, even though bituminous coal used for power generation emits more Greenhouse gas and pollutants than LNG, LNG is taxed at a rate of $16 \%$, while bituminous coal is not taxed at all.

Therefore, ROK clearly need to readjust energy taxation policy. It is essential to impose a consumption tax on bituminous coal used in power generation, and lower the tax on LNG, which is an alternative to electricity. In this respect, industrial uses, such as steel making and cement production, will be exempted from the tax to avoid hampering industrial competitiveness (Ministry of Trade, Industry \& Energy, 2014).

\section{Enhancement of Energy Security}

ROK government also stressed the reinforcement of overseas resource development, in order to strengthen resource development capability.

ROK has been relatively successful in achieving energy quantitative growth. In other words, the amount of oil and mineral resources successfully secured increased over a short period of time, as figure 4 illustrates. Nonetheless, there are still limitations such as excessive emphasis on quantitative growth; weakened investment efficiency; and insufficient infrastructure for growth.

Therefore, ROK's second energy master plan focuses on the following four specific goals, in order to enhance its national energy security:

1) Enhancing Capabilities for Long-term Energy Security

2) Strengthening the Foundation of Public Energy Enterprises

3) Promoting Private Sector Investment in Overseas Resource Development

4) Strengthening Industrial Infrastructure by Training High-quality Workers and Conducting Practical R\&D (Ministry of Trade, Industry \& Energy, 2014).

Table 2. Current and New Policy Paradigm

\begin{tabular}{lll}
\hline & \multicolumn{1}{c}{ Current Policy Paradigm } & \multicolumn{1}{c}{ New Policy Paradigm } \\
\hline Policy Target & $\begin{array}{l}\text { Secure larger amounts of overseas } \\
\text { resources (enlargement of public } \\
\text { enterprises) }\end{array}$ & $\begin{array}{l}\text { Improve the government's capability to } \\
\text { develop resources (Strengthening industrial } \\
\text { competitiveness and creating jobs) }\end{array}$ \\
\hline Key Player & Public enterprises & Public and private enterprises \\
\hline Funding & Financed mainly by public enterprises & Financed mainly by the private sector \\
\hline Method & $\begin{array}{l}\text { M\&A, buying shares in production } \\
\text { fields }\end{array}$ & $\begin{array}{l}\text { Securing operating licenses in exploration } \\
\text { fields }\end{array}$ \\
\hline
\end{tabular}

Source: Ministry of Trade, Industry \& Energy. 2014. "Korea Energy Master Plan: outlook \& policies to 2030." Ministry of Trade, Industry \& Energy. p.110. 
Figure 4. Self-sufficiency Rate

[. Self-sufficiency rate in oil and gas (\%) ]

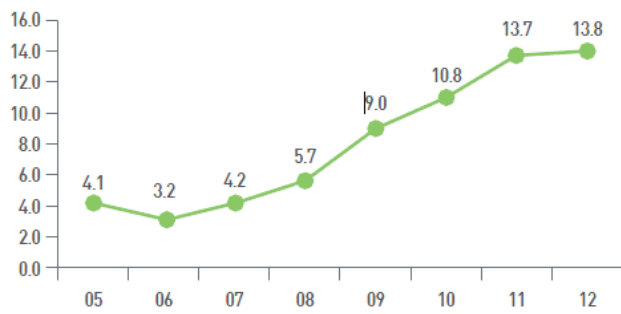

[ Self-sufficiency rate in major mineral resources [\%] ]

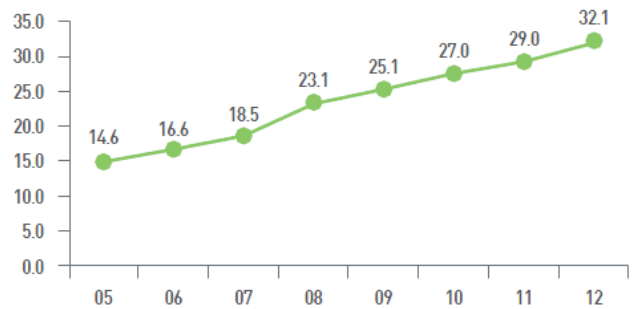

Source: Ministry of Trade, Industry \& Energy. 2014. "Korea Energy Master Plan: outlook \& policies to 2030." Ministry of Trade, Industry \& Energy. p.110.

Establish a stable supply system for each energy source

ROK government's energy plan also emphasizes the establishment of a stable supply system for each energy resources. ROK relatively, as illustrated in figure 4 , secured a stable supply of conventional energy sources, such as oil and gas. More specifically, the second energy master plan aims at diversifying the existing energy routes and expanding domestic stockpiling capacity.

As for oil, ROK hopes to reduce dependence on certain oil exporting countries by diversifying oil import routes, and also to improve the industrial structure by establishing a Northeast Asia oil hub within the Korean Peninsula. ROK government also focuses on the following goals: responding aggressively to changes in the global market, such as the emergence of shale gas, and expansion of the supply infrastructure for domestic stockpiling (Ministry of Trade, Industry \& Energy, 2014). Nonetheless, ROK government also needs to keep up with five mega trends of global energy market.

\subsection{Oil and Gas Supply and Demand Projection}

\section{Oil}

Global short term oil supply and demand is anticipated to improve, and mid- to long-term supply and demand is expected to remain stable. ROK's future oil supply-demand balance is expected to remain stable in the mid- to long-term. In the domestic context, for the short term oil demand increase is due to an increase in the use of feedstock, such as naphtha, for industrial purposes and an increase in demand from the transportation sector with about $1.1 \%$ growth in 2014, despite the downward trend in demand for oil for heating and power generation.

In the mid- to long-term, meanwhile, as table 3 and table 4 illustrate, due to a continuous decrease in demand from non-transport sectors, total oil demand is projected to fall from 2020 at an average annual rate of $0.15 \%$ to approximately 773.9 million barrels by 2035 . For example, ROK's domestic oil dependency is decreasing, as table 3 suggest, $52.0 \%(2000) \rightarrow$ $38.1 \%(2011) \rightarrow 34.1 \%(2020) \rightarrow 26.9 \%$ (2035) (Ministry of Trade, Industry \& Energy, 2014). 
Table 3. Forecast by Source: Total Primary Energy Demand (business-as-usual (BAU))

\begin{tabular}{|c|c|c|c|c|c|}
\hline Source & 2011 & 2025 & 2030 & 2035 & $\begin{array}{l}\text { Average Annual } \\
\text { Growth Rate }(\%)\end{array}$ \\
\hline Coal (share \%) & $\begin{array}{c}83.6 \\
(30.3)\end{array}$ & $\begin{array}{l}100.2 \\
(28.3)\end{array}$ & $\begin{array}{l}107.7 \\
(29.1)\end{array}$ & $\begin{array}{l}112.4 \\
(29.7)\end{array}$ & 1.24 \\
\hline Oil & $\begin{array}{l}105.1 \\
(38.1)\end{array}$ & $\begin{array}{l}111.0 \\
(31.3)\end{array}$ & $\begin{array}{l}107.1 \\
(29.0)\end{array}$ & $\begin{array}{l}101.5 \\
(26.9)\end{array}$ & -0.15 \\
\hline Natural Gas & $\begin{array}{c}46.3 \\
(16.8)\end{array}$ & $\begin{array}{c}64.8 \\
(18.3)\end{array}$ & $\begin{array}{c}69.8 \\
(18.9)\end{array}$ & $\begin{array}{c}73.3 \\
(19.4)\end{array}$ & 1.93 \\
\hline Hydro & $\begin{array}{c}1.7 \\
(0.6)\end{array}$ & $\begin{array}{c}1.7 \\
(0.5)\end{array}$ & $\begin{array}{c}1.9 \\
(0.5)\end{array}$ & $\begin{array}{c}2.0 \\
(0.5)\end{array}$ & 0.70 \\
\hline Nuclear & $\begin{array}{c}32.3 \\
(11.7)\end{array}$ & $\begin{array}{c}59.6 \\
(16.8)\end{array}$ & $\begin{array}{c}65.3 \\
(17.7)\end{array}$ & $\begin{array}{c}70.0 \\
(18.5)\end{array}$ & 3.28 \\
\hline $\begin{array}{l}\text { Renewable \& } \\
\text { Others }\end{array}$ & $\begin{array}{c}6.6 \\
(2.4)\end{array}$ & $\begin{array}{l}16.8 \\
(4.7)\end{array}$ & $\begin{array}{l}18.0 \\
(4.9)\end{array}$ & $\begin{array}{l}18.8 \\
(5.0)\end{array}$ & 4.44 \\
\hline Total & $\begin{array}{c}275.7 \\
(100.0)\end{array}$ & $\begin{array}{c}354.1 \\
(100.0)\end{array}$ & $\begin{array}{c}369.9 \\
(100.0)\end{array}$ & $\begin{array}{c}377.9 \\
(100.0)\end{array}$ & 1.32 \\
\hline
\end{tabular}

Source: Ministry of Trade, Industry \& Energy. 2014. "Korea Energy Master Plan: outlook \& policies to 2030." Ministry of Trade, Industry \& Energy. p.44.

Table 4. Forecast by Source: Final Energy Consumption (business-as-usual (BAU))

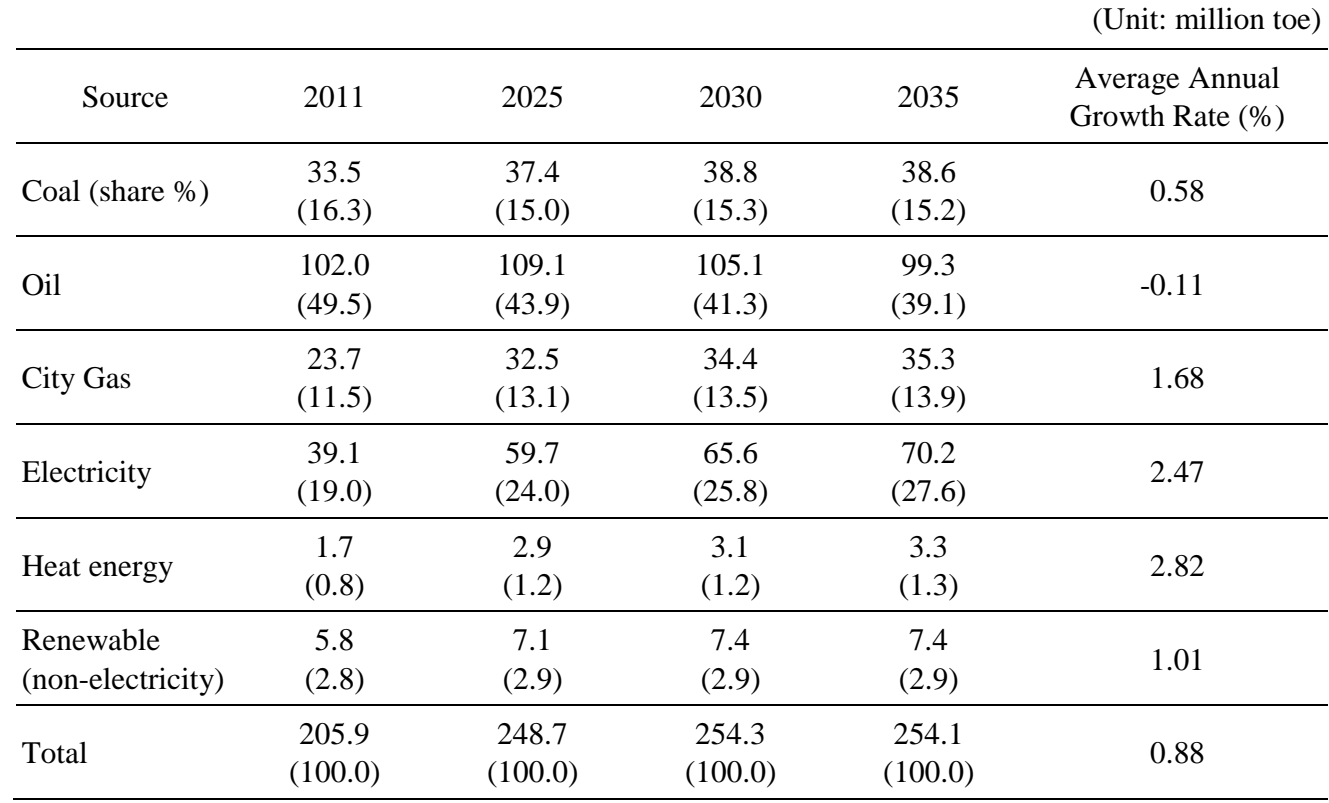

Source: Ministry of Trade, Industry \& Energy. 2014. "Korea Energy Master Plan: outlook \& policies to 2030." Ministry of Trade, Industry \& Energy. p.45. 


\section{Natural Gas}

In general, the Asian natural gas demand is expected to grow, and the supply of natural gas is also expected to increase due to shale gas revolution in North America. As table 3 indicates, ROK's domestic demand for natural gas has also gradually increased at an annual rate of $7.9 \%$ over the past 10 years due to increasing popularity of city gas and increased gas demand for power generation and industrial use. For example, ROK's domestic natural gas demand increased as follows: $18.45(2003) \rightarrow 23.50(2006) \rightarrow 24.64(2009) \rightarrow 36.55$ (million tons) (2012). ROK's mid-to long-term gas demand will be much increased because of high demand for the industrial and transport sectors use. Moreover, gas demand will be very attractive because ROK's domestic gas demand for the power generation sector will depend on Greenhouse gas emission reduction aims, base load power reserve ratios, etc (Ministry of Trade, Industry \& Energy, 2014).

\subsection{Alternative Energy}

During the1970s, Korea invested in 'Alternative Energy' but failed to proceed due to a number of limitations (Kim, 2012). In 1987, Korea enacted the 'Alternative Energy Development Promotion Act,' and launched the new renewable energy technology development projects in 1988 (So, 2011). Yet the IMF crisis in 1998 downgraded the importance of alternative energy and delayed nation's alternative energy program.

Recently, however, in 2008 Korea has reestablished the 'third basic energy plans for renewable energy technology development,' and increased the government budget for renewable energy, as illustrated in table 5. Moreover, the government is currently developing various plans for the promotion of renewable energy industry, as table 6 demonstrates. The plan set the goal of boosting the use of alternative energy with $3.5 \%$ in $2012 ; 6.1 \%$ in 2020 ; and $11 \%$ in 2030 respectively. Until 2030, the core strategy of the plan was to promote R\&D related to industry, to expand industrial infrastructure by enhancing fuel efficiency as well as maintaining low cost. The ROK Ministry of Trade, Industry and Energy has been in charge of the renewable energy program and the Alternative Energy Center for the task of the office of Energy and Resources within the Korea Energy Agency has been also supporting this program.

Table 5. ROK Government budget for Alternative Energy

\begin{tabular}{lrrrrrr} 
& & \multicolumn{4}{c}{ (Won: a hundred million) } \\
\hline The name of the projects & 2007 & 2008 & 2009 & 2010 & 2011 & 2012 \\
\hline Total & 4,350 & 5,326 & 6,877 & 7,958 & 9,283 & 8,309 \\
\hline Alternative Energy technology Development & 1,326 & 2,079 & 2,445 & 2,520 & 3,125 & 2,306 \\
Supply business for Alternative Energy & 1,541 & 1,431 & 1,637 & 1,202 & 1,290 & 1,340 \\
Support for development differences & 270 & 513 & 1,492 & 3,318 & 3,950 & 3,950 \\
Supply loan & 1,213 & 1,303 & 1,303 & 740 & 918 & 713 \\
\hline
\end{tabular}

Source: Kim Jung-In et al. 2012. "A Comparative Study on a Policy of New Alternative Energy." Journal of Northeast Asian Economic Studies 24(1), Northeast Asian Economic Studies Association, p.80. 
Table 6. The present state of Alternative Energy Supply

\begin{tabular}{lccccccccc}
\hline & \multicolumn{1}{c}{ (unit: thousand toe) } \\
\hline Supply & 2005 & 2006 & 2007 & 2008 & 2009 & 2010 & 2011 & 2012 & 2013 \\
Supply percent & $4,879.20$ & $5,225.20$ & $5,608.80$ & $5,858.50$ & $6,086.20$ & $6,856.30$ & $7,582.80$ & $8,850.70$ & $9,879.20$ \\
Solar heat & 2.1 & 2.2 & 2.4 & 2.4 & 2.5 & 2.6 & 2.8 & 3.2 & 3.5 \\
PV & 34.7 & 33 & 29.4 & 28 & 30.7 & 29.3 & 27.4 & 26.3 & 27.8 \\
Bio & 3.6 & 7.8 & 15.3 & 61.1 & 121.7 & 166.2 & 197.2 & 237.5 & 344.5 \\
Waste & 181.3 & 274.5 & 370.2 & 426.8 & 580.4 & 754.6 & 963.4 & $1,334.70$ & $1,558.50$ \\
Waterpower & $3,705.50$ & $3,975.30$ & $4,319.30$ & $4,568.60$ & $4,558.10$ & $4,862.30$ & $5,121.50$ & $5,998.50$ & $6,502.40$ \\
Wind power & 918.5 & 867.1 & 780.9 & 660.1 & 606.6 & 792.3 & 965.4 & 814.9 & 892.2 \\
Geothermal & 32.5 & 59.7 & 80.8 & 93.7 & 147.4 & 175.6 & 185.5 & 192.7 & 242.4 \\
Hydrogen Fuel cell & 0.5 & 1.7 & 1.8 & 4.4 & 19.2 & 42.3 & 63.3 & 82.5 & 122.4 \\
Marine resources & - & - & - & - & - & 0.2 & 11.2 & 98.3 & 102.1 \\
\hline
\end{tabular}

Source: http://www.index.go.kr/potal/main/EachDtlPageDetail.do?idx_cd=1171.

From 2011 to 2015, Photovoltaic (PV) and wind power oriented investment plan launched with 33 trillion Won. This plan includes PV with about 20 trillion, wind power with about 10 trillion, fuel cell with about 1 trillion, as well as bio energy with about 1 trillion Won. As table 6 indicates, in particular, the supply portion of PV between 2005 and 2013 has astronomically increased.

Moreover, the third basic plans aimed at establishing grounds for short termcommercialization of renewable energy within 5 to 10 years, and replacing energy sectors by renewable energy with securing core technology in the long term. Also another objective of third basic plans is to promote private led of renewable energy industry (So, 2011).

In fact, RPS (Renewable Portfolio Standards) which was a government's mandatory policy of substituting alternative energy for certain amount of electric power production came into effect in 2012. This policy focused upon reducing CO2 emission and expanding the market size, while enhancing competitiveness for alternative energy. In 2012, the electricity supplier had to substitute alternative energy for $2 \%$ of the total electric power production. And this ratio must be increased by $10 \%$ until 2020 . It is expected that the electricity supplier must abide by the rules in order to increase the proportion of renewable energy for the national power generation ("RPS," http://www.ecotiger.co.kr/news/ articleView.html?idxno=14499 (date: 2015. 9. 9). Besides that, RPS is demanding the supplier's obligation through the policy improvement, gathering opinions from experts, and managing the market with the supply certificate, monitoring the proper use or illegal abuse of equipment (Nam, 2013).

\subsection{Natural Gas}

In the mid-1980s Seoul introduced governmental tax incentives to promote widespread use of natural gas. In the course of fast expansion of South Korea's natural gas industry from 1987 to 2002, ROK established a nationwide trunk pipeline network, which has made ROK 
one of the global most dynamic gas markets. Natural gas continued to grow in ROK, both because of its convenience and because of environmental merit. Accordingly, it is anticipated that gas demand in ROK is to grow by $150 \%$, from 20 billion cubic meters (bcm) in 2000 to $53 \mathrm{bcm}$ by 2020 .

ROK is the second largest importer of liquefied natural gas (LNG) next to Japan at the current. And ROK is also home to the world's largest LNG importer, Korean Gas Corporation (Kogas). Kogas has a monopoly over the all of ROK's gas imports, which thus far are entirely in the form of LNG, which generates some social agenda at home from the energy security aspect. Thanks to privatization efforts started in 1999, ROK has allowed POSCO (a large steel maker) to make a rare "spot" purchase of 500,000 tones of LNG in 2006. POSCO and K-Power have also signed a long term LNG contract in 2004 for 550,000 and 600,000 million tons respectively of LNG from Indonesia's Tangguh project delivered by the end of 2008. Kogas's imports have traditional came from Southeast Asia, but purchased a great deal of volume from Qatar and Oman, and additionally made a contract with the U.S. shale gas in 2012 (Ahn and Jones, 2008).

KOGAS's purchase of Southeast Asian volume has gradually decreased. For example, Indonesia is an example of such doubt. Much of ROK's LNG in the 1990s came from Indonesia; however, the future of Indonesia's LNG industry is uncertain. Due to a lack of favorable investment policies and general resource nationalism, this OPEC country turn into a net importer of oil in 2004 and plans to further develop its LNG for export is currently in limbo. An overall push to develop a domestic gas market is emerging to make up for this energy gap. Indonesia already has to import LNG from other countries in order to meet its existing long-term supply contracts. Therefore, ROK decided to increase the LNG volume from the Middle East.

South Korea began to import LNG from Oman, Yemen and Qatar in the late 1990s. By 2020 a significant portion of Korea's LNG imports will be delivered from the Middle East, especially Qatar volume. Accordingly, it is important to point out that South Korea's LNG will increasingly have to travel long distances through world energy chokepoints such as the Hormuz and Malacca straits. Moreover, the problem is that the Middle Eastern liquefaction capacity is in shortage these days. In other words, ROK's traditional LNG suppliers such as Yemen, Oman, and the United Arab Emirates have all virtually exhausted new supplies. And even Qatar, which is the world's largest LNG exporters, has already produced approximately $80 \%$ of its potential LNG supplies allegedly. These shaky Middle Eastern options make the U.S. and Russia an extremely attractive source of gas for ROK. At the moment, ROK purely relies on LNG, so the Russian gas pipeline and the U.S. shale gas would definitely help South Korea diversify its sources of gas. For Korea, the Russian PNG is extremely attractive as it could diminish risk among the multiple parties involved (both government and private), compared with bilateral LNG deals. Both Russian and the U.S. gas can balance its reliance on tanker gas coming from Qatar (Ahn and Jones, 2008).

\section{THE NEW ENERGY SECURITY CONCEPT}

It is essential to point out that not many people realize the exact meaning of the concept of energy security. This is considered to be one of the major energy security threat at both inside and outside the country these days. For the ignorance of this particular term generates for the national leader to take irrelevant and irrational energy security decision making, and 
this also leads to the failure of domestic energy policy and energy diplomacy. Energy security is an important element of national and regional security today. It is a strategic factor in ensuring the economic development and stability of states. Because of the "increasing importance of traded energy, increasing dependence on Middle East Oil, no sign of slackening demand rise, continuing volatility of oil prices, and environmental and sustainability concerns," energy issues are an increasingly important part of the security agenda in international relations in general (Andrews-Speed, 2003).

Energy security is defined as the securing of reliable and affordable energy supplies that are sufficient to support social, economic, and military needs, while at the same time being environmentally sustainable (Doh, 2003; Willrich, 1975). Willrich defines energy security as, first, the guarantee of sufficient energy supplies to permit a country to function during a war; and second, and more broadly, the assurance of adequate energy supplies to maintain the national economy at normal levels. He argues that the first definition is too restrictive, and the second too permissive and expansive. Therefore, he proposes that for most purposes, the definition of energy security as the securing of reliable and affordable energy supplies that are sufficient to support social, economic, and military needs, while at the same time being environmentally sustainable is the most plausible approach (Willrich, 1975). More specifically, "in a state which enjoys energy security, consumers and their governments are able to believe that there are adequate reserves from sources at home or abroad, and production and distribution facilities available to meet their requirements in the near future, at costs that do not put them at a competitive disadvantage or otherwise threaten their wellbeing (Lieber, 1980; Deese, 1979/1980)." In other words, energy security emphasizes economic factor, which is namely, affordable prices. On the other hand, energy insecurity arises when the welfare of citizens or the ability of governments to pursue their other normal objectives are threatened, either as a result of physical failure of supplies or as a result of sudden and major price changes (Belgrave, Ebinger, and Okino, 1987). In this sense, it can be argued that energy security constitutes an important part of economic security because it is the core prerequisite for sustainable development (Doh, 2003).

In traditional terms, one way to estimate the level of energy security is to measure the extent to which a country is dependent on particular types of energy and whether these can be obtained within its territory or must be imported. In the latter case, a second question emerges relating to the level of the dependency, the diversity of foreign sources, the relative vulnerability of the source areas to political turmoil, and hostile control. Similar questions apply to transportation routes and carrying systems. In the end, as most people realize, the energy security of a state is evaluated by its level of self-sufficiency and its ability to adapt to temporary and prolonged supply interruptions without serious economic and military consequences (Stares, 2000).

More specifically, a useful distinction can be made between energy importing and exporting countries. An importing country is primarily concerned with the security of its energy supplies. However, each importing country tends to view foreign energy supplies as more or less vulnerable to interruption (Willrich, 1975). Although interruptions, disruptions, and manipulations of existing supply arrangements can be caused by accidents and natural disasters, they are more vulnerable to potential political instability, economic coercion, military conflict, and terrorist acts. These concerns apply not only to the source of energy supplies but also to the routes and means by which they are transported (Yergin, 1998; Stares, 2000).

Energy exporters, on the other hand, are concerned with access to markets and security of 
demand. An exporting country may perceive energy security as national sovereignty over its energy resources, or it may view it more broadly as sovereignty over resources plus guaranteed access to foreign markets (Willrich, 1975). Moreover, an exporter may view security as sovereignty plus market access plus financial security for the assets it receives in exchange for energy raw materials. An exporter may adopt, as a result of sovereignty over its basic raw materials, a concept of energy security that includes guaranteed access to foreign markets. In short, demand security may be as important to energy exporters as supply security is to importers. As Willrich notes, "this raises possibilities for mutually beneficial negotiations between exporters and importers, based on overlapping areas of interest in stability and equilibrium. In addition to sovereignty and market access, an exporter may extend the concept of energy security to cover financial security for the investments made with its export earnings. This scenario may seem exaggerated but energy resources below ground are a precious national heritage. Once extracted, that heritage can easily be lost by an improvident government or eroded by inflation (Willrich, 1975)."

What seems to be more important about energy security these days is that the concept of energy security is no longer confined the term 'access' or 'diversification'. These two above concepts were the primary issues during the 1920s and 1960-70s, as previously mentioned. The millennium concept of energy security stretches far beyond access and diversification. It expands up to the resilience, integration, not to mention information. Moreover, the national government's energy diplomatic skill is also another important component of energy security these days. This includes the political leaders' basic knowledge about energy security and tactics of energy diplomacy and energy mix plan. It is quite stunning to point out that a number of national leaders are not quite familiar with the exact concept of energy security, which is considered to be national energy security threat for the longer term. More important, energy diplomacy is the part of energy security these days. In other words, the notion of energy security is no longer the separate meaning from energy diplomacy.

\section{ROK'S ENERGY SECURITY OBJETIVES}

\subsection{What is the most important current issue and how is the country trying to solve it?}

From the ROK perspective, the primary objectives of energy security are as follows:

1) ROK government hopes to implement nation's smart future power mix plan. ROK has promoted the use of nuclear power and renewable energy in the past few years despite the Fukushima incident. Nonetheless, this has turned out to be a major policy failure. This is the prevailing consensus among energy experts in Korea. It is essential for the ROK government to turn to more natural gas use considering the recent dramatic increase of micro dust in the nation in the past few years. Also, the country must reconsider its most recent energy policy of building additional nuclear power plants, and definitely should cut down the use of coal. ROK's energy mix policy will be more elaborated in the later part of this paper.

2) How to frame DPRK energy security and thus how to prepare for the energy security framework for the possible reunified Korea is one of ROK government's most important energy security objectives. DPRK's energy security has completely broken down for the past several decades and is desperately in need of foreign assistance at the moment. Accordingly, natural gas remedy seems to be a perfect solution to DPRK due to its diverse supply options 
either from Russia or from the North American states. It is essential to point out that DPRK's energy security issue should not be accounted from the commercial perspective but the larger geo-political framework in the longer term (Ahn, 2013).

3) Accessing the Russian oil and gas in the eastern Siberian region is another key component of ROK's major energy security priority. In fact, ROK is located in the middle of between energy continental power group and sea power. And recently following the shale gas revolution, ROK was actively courted by both sides to join their each alliance. In particular, Eastern Siberia turns out very promising region considering the short distance advantage, just as Russian-German energy rapprochement demonstrated in the past few decades. Recently, natural gas pipeline project linking two Koreas and Russia has been actively brought to the diplomatic table, and still remains the focal point of Northeast Asian energy security cooperation. At the same time, Sino-Russian energy relations should be carefully examined and analyzed in detail to understand the current Northeast Asian energy flow. It is crucially important to point out that Korea is the perfect energy partner for Russia more than anybody else such as China, Japan, and India. Energy cooperation between Russia and South Korea is extremely important but both sides are not moving fast as it should be. Gas from Russia's eastern Siberian field has the potential to not only drastically reduce Northeast Asia's energy shortage but also help diversify Northeast Asia's traditional sources of energy from the Middle East and Southeast Asia.

Up to this stage, however, the potential for Russian natural gas reaching any Northeast Asian country including ROK, has been delayed for almost two decades due to following reasons:

- Delayed gas price negotiation between Russia and China in 2007 and 2008: oil cooperation is relatively moving smooth yet gas still remains problematic in Northeast Asia. Nonetheless, gas flow is more important to Korea, China, Japan and Russia, compared to oil since gas is global and regional energy phenomena.

- Asset disputes between Gazprom and BP-TNK; and Gazprom and Rosneft: Korean government welcomed Gazprom's complete take over Kovykta's asset because it would facilitate government to government cooperation and development of gas project more quickly. And yet, power struggle within Kremlin turns out the key issue to delay Russian gas to Northeast Asia. In fact, Putin prefers Rosneft with Igor Sechin to Gazprom with Alexei Miller.

- Global economic crisis was the major hurdle for energy cooperation between Russia and South Korea in the late 1990s.

- The politics of route determination has been very sensitive and the primary discussion of Russian gas transfer to Northeast Asia. Although to route the pipeline via North Korea and Mongolia would economically makes more sense, government and private sector sensitivities have led to proposed routes that circumvent the two countries thus driving up costs of any such pipeline. And yet transit country discussion still remains the focal point of pipeline gas mechanism.

- Confidence and gas investments. Natural gas is genetically more difficult to trade than oil and requires much more confidence, guarantees, and money from investors and governments. In this respect, the lack of confidence among states in the region diminishes the possible natural gas collaboration.

- China factor. China's market is a key to Russian PNG success but not a necessary condition. Despite plans for further gas market development, however, China's reliance 
on Turkmenistan, Kazakhstan, Myanmar and Australia has led to a soft market for relatively high-priced gas. And yet, China-Russian gas cooperation is the main key for Russian gas transfer to Asia. In other words, it is highly unlikely to anticipate Russian gas flow to Asia without Chinese market (Ahn and Jones, 2008).

- Wary Kremlin's resource diplomacy. Rising oil prices has traditionally given Russia impetus to use energy as a political weapon. In Eastern Europe, Near Abroad, or elsewhere except toward Western Europe, Russia tended to pull some political strings in the course of gas diplomacy. East Asia still perceives Russia as a bug bear in the gas transfer from Russia.

4) how to build further strong energy alliance with the U.S.: ROK and the U.S. could elevate current strong alliance beyond up to the level of special energy alliance through Free Trade Agreement between the two sides. In particular, two sides could tighten energy alliance with the transfer of the U.S. natural gas and crude oil. Perhaps the U.S. could use Korean natural gas terminal to expand its Asian export market in the longer term.

5) how to establish global oil and gas hub in the Korean peninsula: Korea is where the future massive amount of Russian gas and the North American gas will be imported simultaneously and posits a perfect location to build global scale of natural gas import \& export station, especially in the east coast of country.

6) how to design nation's energy diplomacy and security policy effectively: proper energy security program should be introduced at each level of energy governance: presidential leadership, congress, ministry, and military. Leaders in the Korean Peninsula are clearly lacking in the exact concept of energy security and this often misleads national energy policy flaw.

\subsection{What are the biggest foreseen challenges in the near future?}

Within the realm of energy cooperation in Northeast Asia, the major concern is that politics always outplay economics. In other words, political huddles including the inherent complexities of Northeast Asian relations such as the balance of power relations among China, Russia, and the U.S.; the lack of mutual trust between nations, DPRK nuclear proliferation; estranged ROK-Japan relations, all hinder further energy cooperation in the region. Moreover, the general lack of understanding of the proper concept of energy security among Northeast Asian top leaders is also prevalent; the new threat of nuclear power plants danger as well as non-transparency of energy industry and energy market in certain countries still remain potential challenges for the region to ensure energy security in the future.

\subsection{What role does the U.S.- Japan- Korea alliance play for the country's energy security?}

In comparison with Sino-Russian energy alliance or potential Sino-Russian-Korean energy alliance, the U.S.-Japan- Korean energy alliance could create more reliable and predictable energy market system based upon the decades of strong political and military alliance. Specific elements of energy alliance cooperation may include natural gas (shale gas) transfer and the collaboration over the gas related industry such as gas automobile industry. In this sense, it is essential to anticipate possible U.S crude oil transfer to Japan and Korea through free trade agreement settings. 


\subsection{Off-Shore Resource Development}

There is also interest in development of offshore energy resources in Japan and the ROK: what impact does this have on energy policy, cooperation among the three countries (and others)?

Quite frankly, there is no active offshore energy resources development in the Korean offshore area at this stage. Indeed there are massive gas hydrate reserves in Dokdo Island in the East Sea and Sector 7. Unless the current conflict between ROK and Japan resolves, however, it is quite difficult to see further energy cooperation between the two sides. Nonetheless, the U.S. is very keen on Sector 7 development since this project could give Korea more impetus to engage in both the East China Sea and South China Sea. Besides that, there was a brief idea of natural gas co-buying scheme right after Fukushima Incident from the Japanese and Korean side, yet the plan was abandoned with no actual practical benefit.

Perhaps, three nations could work on framing energy security in the DPRK including oil exploration in the DPRK offshore area in the future instead. Furthermore, three nations could work on energy transport related sea route safety regulation activities or sea lane communication issues as well as nuclear safety regulation in the future.

Finally, once again, it is essential to examine the current development and obstacles of Sino-Russian energy relations as well as the possible energy transfer among China, Russia and the Korean Peninsula. This also leads the U.S., Japan and Korea to implement the right proper energy strategy to form new energy alliance among three nations.

\section{ENERGY DIPLOMACY}

There are a number of problems for South Korea's energy diplomacy. Under Park Geun Hye's administration, most of energy diplomacy activities virtually stopped to function.

There are two explanations for this failure. First, energy security concept is simply missing among top leadership including at the legislative, judicial body not to mention presidential office.

- Energy security educating program must be introduced at the moment. Politicians are seriously in need of learning the true concept of energy security.

- Energy security should not be a part of party politics or election agenda, even though it is quite tempting and lucrative political agenda.

- It is the most important element of national security.

- Yet, Korean leadership seems like they are not aware of the importance of energy security.

Secondly, Energy was highly politicized within Korean soil. From the begging of her term, President Park really wanted to distance herself from the former Lee Myung Bak administration in terms of energy policy. There were a number of energy related scandals and corruption charges revealed after Lee Myung Bak's administration. Accordingly, at the current, a number of energy companies are still under the government inspection and every energy business activities led by state energy companies have been the primary target for the annual government inspection.

From the energy security perspective, excessive government intervention in energy diplomacy or activities are not considered to be desirable because with too much government 
inspection and regulation, it is highly likely that energy market or energy diplomacy is beginning to mal- function.

Nonetheless, South Korea's primary objective of energy diplomacy is diversification of energy import market: 4 different channels. 1) the Middle Eastern oil and gas; 2) Southeast Asia; 3) Russia and the former Soviet Union; and 4) new North American gas market.

It is quite essential to point out that the ROK government desperately needs to keep up with the 5 mega trends of global energy market these days. At the same time, the Korean government recently also set up a few specific energy policy goals for Northeast Asian energy cooperation:

1) how to frame or ensure energy security in North Korea;

2) how to establish Northeast Asian oil and natural gas hub facilities in the Korean Peninsula; and

3) how to set up multilateral framework for the safety of nuclear power generation: TRM (Top Regulators' Meeting) and TRM plus. TRM stands for which guides nuclear power safety among China, Japan and South Korea.

\section{ENERGY POWER MIX}

Korea's most recent energy power mix plan is too much oriented toward nuclear power generation and renewable energy. Korea, just like Japan, depends on foreign energy resources: the rate of current energy independence is only 3\%: Here 3\% includes hydropower, anthracite, and a small segment of renewable energy. Other than that, as previously mentioned in the early part of this paper, Korea imports most of energy including oil, coal and natural gas.

Nonetheless, in a traditional sense, Korea's current energy mix is generally perceived as stable for the global standard because energy resources for power generation were diversified, compared with early 1980s when oil used to be the primary energy for power generation. Now, coal, nuclear power and natural gas replaced oil for power generation. In short, external factor, mostly, global energy market situation and specifically energy price have been the most dominating force or variable to determine Korea's energy power mix plan.

Most recently, however, four domestic constraints create the problems of energy power mix in Korea:

1) Korea's overdependence on nuclear power generation.

2) Korean government did not keep up with the mega trend of global energy market: especially did not consider natural gas booming phenomenon into the national energy power mix plan. Simply underestimated the role of natural gas importance.

3) Overvalued the capacity of renewable energy: renewable energy is neither base load energy like nuclear power or coal nor peak load energy like LNG.

4) The lack of energy reform, specifically regarding energy price and energy taxation. Korea's energy reform is much outdates and need to be fixed. In other words, energy industry needs to be restructured and desperately in need of significant reform (Ryu and Ryu, 2013).

Moreover, in Korea there are too many government directed energy planning such as 
basic energy planning; power supply \& demand basic planning; long term natural gas supply and demand planning; renewable energy planning; energy utilization basic planning and global energy diplomacy strategic planning. And the problem is that each of many energy planning is not inter-connected with one another. They were planned separately with no consideration of other planning. Therefore, ROK government desperately needs to bring all of these individual plannings together, and also seek to rearrange in terms of order. Most important, between the most recent Korea's energy power mix plan number $6^{\text {th }}$ and $7^{\text {th }}$, the natural gas use was not taken into consideration into the basic national energy power mix plan at all (Ryu and Ryu, 2013).

\section{ENERGY SCANDAL}

South Korea depends heavily on its self-generated nuclear power. Meanwhile, a nuclear scandal took place in South Korea, when the country faced a series of shutdowns, of nuclear reactors because of fake warranty documents a few years ago. This incident was exposed to the public during the September 2013's nationwide blackout period. This whole scandal demonstrates corruption at Korea Hydro and Nuclear Power (KHNP), the state-run company that was responsible for the operation of country's nuclear power plant.

Through this nationwide scandal, the deep ties between KHNP and the related industry was revealed. And these special ties, labeled as the nuclear mafia, generated serious social and technology problems in Korea. Specifically, a number of illegal activities such as putting fake warranties into substandard parts of reactors, failed safety checks of control cables that are in charge of shut down reactors in the event of an emergency were exposed.

As far as the fake documents are concerned, for example, the documents dated back to 2012. During November 2012, 2 nuclear reactors were suspended by the country after discovering that the parts were supplied with fake certificates. Also, on October 10, 2013, South Korea indicted about 100 people, which included a top former state utility official with the charges of scandal. Officials further noted that they will bring those reactors that were suspended for inspection and replacement of parts. Moreover, on 7 February 2014, the Nuclear Safety and Security Commission declared that its investigation since mid-2013, they found eight cases out of 2,075 samples of foreign manufactured reactor components that were supplied with fake documents. Although the names of dealing countries remains undisclosed.

It is equally interesting to point out that this phenomenon is quite prevalent throughout the planet, not just in Korea. After the Fukushima incident, quite a few energy expert had already anticipated the nuclear power will come back eventually because of strong ties between the state and industry which had persisted for several decades. In fact, a nuclear Watergate type of incident is just at the tip of the iceberg of the whole energy industry corruption throughout the world, especially compared with the oil and gas sector. Traditionally within energy sector, there is a strong bond or ties which have been established between politics and energy industry. It is really difficult to crush this invincible fortress which had been consolidated over the last century. This type of exclusive fortress substantially controls global energy market and politics, and is deeply engaged in many energy related activities: creating energy company, deciding oil price and electricity price, controlling over national power plant, M\&A of energy companies, and most importantly deeply involved in all kinds of national election process. 
And it is striking to point out that environmental group actually supports nuclear power generation since nuclear power plant produces low $\mathrm{CO} 2$ emission, which is a very interesting phenomenon throughout the world. Despite the Fukushima incident, especially in East Asia and the United States, with the help of climate change notion, nuclear power generation became so fashionable these days with zero greenhouse gas emission.

\section{CONCLUSION}

This paper reviewed the ROK's most current energy security priorities and problems as well as energy mix plan. This study revealed that under the President Park's administration, ROK has faced a number of energy security problems at the national level. Almost nation's energy diplomacy has virtually stopped to function for mostly domestic political reasons. Furthermore, nation's energy security has been endangered because ROK's energy security policy, for example, energy master plan has poorly executed with no concrete set of proper goals and with no rational choice of which energy is more important to one another.

Nonetheless, this study outlined ROK's most urgent energy security task at the moment and how the country should response to these specific issues. This paper argues that the current problems of ROK's energy security and the recent deadlock of ROK's energy diplomacy stemmed from the general ignorance of the exact definition of energy security at the national level among energy policy makers, various political groups including top leadership, interest group, academia as well as media. In the course of harsh political turmoil and perhaps at the time of most divided national public opinion virtually over every issue ever in ROK's history, energy security issue has also become the most sensitive and the most provocative political agenda in the ROK's domestic politics.

Hence, not a single national energy company dares to expand its new abroad energy business at this moment. Nor do relevant energy policy makers in the ROK's government want to discuss energy security policy at first, while just looking at what President Park will have to say about energy policy based upon limited resources. This is even more depressing when we look at other Japanese and Chinese leaders are most aggressively pushing forward their energy diplomacy especially given the current low global oil price. ROK top officials are at least simply concerned with $\mathrm{CO} 2$ emission and renewable energy, while not realizing the importance of natural gas and the true meaning of energy security. Unless there is a revolutionary change in the thinking of the new energy security concept, it is highly likely that ROK will face significant energy security disarray in the upcoming few decades.

It is essential to point out that national leaders, parliament members and energy policy makers should keep up with the global energy mega trends. And most important, energy security policy and energy diplomacy should be depoliticized in ROK as soon as possible. It is even more pessimistic to see national leaders in the Blue House, the National Assembly, prosecutor's office, and the parties look at energy security issue as a political decoy or public hatred issue. In conclusion, it is even more important to understand that energy diplomacy is the continuation of domestic energy security issue, and energy diplomatic skill is also the important component of today's national energy security. It is equally important for political leaders to remember that the notion of energy security does not mean only diversification or access any longer. It also includes national leaders' basic knowledge, vision, and the capacity to understand the nexus between energy and security. 
Article Received: 12-21-2015 Revised: 12-29-2015 Accepted: 12-31-2015

\section{REFERENCES}

Ahn, Se Hyun. 2007. "Energy Security in Northeast Asia: Putin, Progress, and Problems." LSE Asia Research Centre (ARC). Working Paper 20.

Ahn, Se Hyun. 2009. "The Fate of Kovykta.” Northeast Asia Energy Focus 6(1):12-19.

Ahn, Se Hyun. 2010a. "Energy Alliance among South Korea, Russia and China: Potentials and Problems." The Journal of International Studies 15(1):105-135.

Ahn, Se Hyun. 2010b. "Framing Energy Security between Russia and South Korea?: Progress, Problems, and Prospects." Asian Survey 50(3):591-614.

Ahn, Se Hyun. 2012a. "South Korea's ODA Policy and Energy Diplomacy Linking Strategy toward Africa: Lessons from ENI and China." The Journal of International Studies 17(1): 89-118.

Ahn, Se Hyun. 2012b. “The Anatomy of China's ODA Policy-Energy Diplomacy Link Strategy toward Africa: Reasons of Success \& Challenges.” East West Journal 24(1):109-140.

Ahn, Se Hyun. 2013a. "Framing Energy Security in North Korea?: Natural Gas Cooperation in Northeast Asia." The Journal of International Studies 18(1):67-103.

Ahn, Se Hyun. 2013b. "Framing Multi-lateral Energy Security Framework in Northeast Asia?: Lessons from KEDO and ECT.” East West Journal 25(4):87-110.

Ahn, Se Hyun. 2013c. "North Korea's Energy Conundrum: Natural Gas Remedy." Asian Survey 53(6):1037-1062.

Ahn, Se Hyun. 2014. "Anatomy of the New Energy Great Game among the United States, Russia and China in the Middle East: The US Energy Belt Building Strategy and its Origins." Review of International and Area Studies 23(4):65-101.

Ahn, Se Hyun, and Michael T. Jones. 2008. "Northeast Asia's Kovykta Conundrum: A Decade of Promise and Peril." Asia Policy The National Bureau of Asian Research, NBR 5(1):105-140

Ahn, Se Hyun, and Bo Ram Kim. 2015. "The Anatomy of International Political Economy of the Keystone XL Pipeline Project: Obstacles and the United States Energy Politics Mechanism." East West Journal 27(1):169-203.

An, Ji-Woon. 2014. "A Prospect on Energy Technology using TM Prototype : Focused on an application of New and Renewable Energy" Energy Economics Institute.

Bak, Jung-Sun. 2014. "A Policy Change and Market Analysis on International New and Renewable Energy.” Energy Economics Institute.

Bak, Sang-Yong et al. 2014. "Exploring the Future of Renewable Portfolio Standard in the Korean Electricity Sector." Journal of The Korean Society for New and Renewable Energy Spring.

Belgrave, Robert, Charles K. Ebinger, and Hideaki Okino, ed. 1987. Energy Security to 2000. Boulder: Westview Press.

Deese, David. 1979. "Energy: Economics, Politics, and Security." International Security 4(3):140-153.

Doh, Hyun Jae. 2003. "Perspectives and Measures for Energy Security in the $21^{\text {st }}$ Century." Korea Energy Economics Institute Report No. 03(07).

Epstein, Lita, C.D. Jaco, and Julianne C. Iwersen-Neimann. 2003. The Politics of Oil. 
Indianapolis, IN: Alpha.

Herberg, Mikkael. 2015. "The National Bureau of Asian Research, Seattle, Washington, USA." Personal interview, Seattle, Washington. October 1, 2015.

Hippel, David von, and Peter Hayes. 2012. "Foundation of Energy Security For the DPRK." Korea Energy Economics Institute.

Jones, Bruce. David Steven, and O’Brien Emily. 2014. "Fueling a New Order? The New Geopolitical and Security Consequences of Energy." The Brookings Institution.

Kang, Jung Min. 2015. "The Natural Resource Defense Council, Washington, DC, USA." Personal interview, Washington DC. December 4, 2015.

Kandiyoti, Rafael. 2008. Pipelines: Flowing Oil and Crude Politics. New York: I.B. Tauris $\& \mathrm{CO}$.

Kalicki, Jan H., and Goldwyn L. 2005. Energy and Security. Washington, DC: The Johns Hopkins University Press.

Kim, Jung-In et al. 2012. "A Comparative Study on a Policy of New Alternative Energy." Journal of Northeast Asian Economic Studies 24(1).

Kim, Jung-moon. 2015. "RPS” Eco Times, August 31. Accessed September 9, 2015. http:// www.ecotiger.co.kr/news/articleView.html?idxno=14499.

Klare, Michael. 2001. Resource Wars: the New Landscape of Global Conflict. New York: Metropolitan Nooks.

Klare, Michael. 2009. Rising Powers, Shrinking Planet. New York: A Holt Paperback.

Korea Energy Economics Institute. 2014. "2014 Energy Info. Korea.” Korea Energy Economics Institute.

Korea Energy Sector and Green Economy Review. 2014. "Lesson from the Region, Korea Energy Economics Institute." Korea Energy Economics Institute.

Korea Energy Master Plan. 2014. "Outlook \& Policies to 2035." Ministry of Trade, Industry \& Energy (MOTIE), Energy and Resources Policy Division, Office of Energy and Resources.

Lee, Chyul-Yong. 2014. "A Study on An Estimate of Willingness to Pay and Improvement Strategies of Social Acceptance.” Energy Economics Institute.

Lee, Gwang-Won. 2015. "A Study on the Implementation Process of Policy for Renewable Energy to Overcome Energy Crisis: Focused on Policy Network Analysis of the Solar City Daegu Project." Journal of Korea Association For Crisis and Emergency Management 11(3). Crisis and Emergency Management Theory and Praxis.

Lee, Sung Kyu. 2011. "Russian energy expert, Korea Energy Economics Institute, Seoul, Korea." Personal interview, Seoul, September 19, 2011.

Lieber, Robert J. 1980. "Energy, Economics and Security in Alliance Perspective," International Security 4(4):139-163.

Ministry of Trade, Industry \& Energy. 2014. "Korea Energy Master Plan: outlook \& policies to 2030." Ministry of Trade, Industry \& Energy.

Nakano, Jane. 2015. "Center for International Strategic Studies, Washington, DC, USA." personal interview, Washington DC. December 4, 2015.

Nam, Gi-Woong. 2013. "A Policy on New and Renewable Energy." The Korean Solar Energy Society.

Normal, James. 2009. The Oil Card: Global Economic Warfare in the $21^{\text {st }}$ Century. Walterville, OR: Trine Day LLC.

Paik, Keun Wook. 2013. “Interview.” Oxford Energy Institute. London. January 30, 2013.

Philip, Andrews-Speed. 2003. "Energy Security in East Asia: A European View." 
Presentation material at the Symposium on Pacific Energy Cooperation 2003, Tokyo, February 12-13, 2003.

Reisinger, William. 1992. Energy and Soviet Bloc. Ithaca: Cornell University.

Ryu, Ji Chul, and Kwon Hong Ryu, 2013. "Policy Implication on Stable Mid-term and Long

Term Energy Mix" October 15. Accessed October 19, 2013. The Institute for the

Future of the State Policy Report, on http://www.ifs.or.kr/modules/board/bd_view. asp?no $=114 \&$ ListBlock $=\&$ gotopage $=1 \&$ Pagecount $=1 \&$ sk $=$ bd_title $\& s v=\& i d=$ resear ch\&ca_no $=16 \&$ mncode $=\& l e f t=\&$ top $=\&$ author $=\&$ top $=2$.

Stares, Paul B. 2000. "Introduction and Overview." In Paul B. Stares, ed., Rethinking Energy Security in East Asia (Tokyo: Japan Center for International Exchange, 2000).

Venn, Fiona. 1986. Oil Diplomacy in the Twentieth Century. New York: St. Martin's Press.

Willrich, Mason. 1975. Energy and World Politics. New York: The Free Press.

Yergin, Daniel. 1988. "Energy Security in the 1990s." Foreign Affairs 67(1):111-132.

Yergin, Daniel. 2008. The Prize: The Epic Quest for Oil, Money and Power. New York: Free Press.

Yergin, Daniel. 2006. “Ensuring Energy Security?” Foreign Affairs 85(2):69-82.

Yergin, Daniel. 2011a. Author's Interview. Washington, DC. July 5, 2011.

Yergin, Daniel. 2011b. The Quest. New York: The Penguin Press.

Statistics Korea. 2014. "The present state of Alternative Energy Supply" Accessed September 9, 2015. http://www.index.go.kr/potal/main/EachDtlPageDetail.do?idx_ $\mathrm{cd}=1171$.

Se Hyun Ahn, Professor of the Department of International Relations \& Director of the Center for Energy Security Strategic Studies, University of Seoul, Seoul Siripdae-ro 163, Dongdaemun-Gu, Seoul. Tel: +82-02-6490-2045 E-mail: ahns@uos.ac.kr 